\title{
Motif Become Drivers of Online Transportation in The City of Semarang
}

\author{
Mahmud Yunus ${ }^{1}$, Etty Soesilowati ${ }^{2}$, Dewi Liesnoor Setyowati ${ }^{3}$, Thriwaty $\mathrm{Arsal}^{4}$ \\ \{mahmudyunustegal@gmail.com ${ }^{1}$,ettysoesilowati@yahoo.com ${ }^{2}$, dewiliesnoorsetyowati@gmail.com ${ }^{3}$ \}
}

Universitas PGRI Semarang Jalan Sidodadi Timur Number 24-Dr. Cipto Semarang Indonesia ${ }^{1}$, Universitas Negeri Semarang Sekaran Gunungpati Semarang Indonesia ${ }^{2,3,4}$

\begin{abstract}
The paper aims is to explore the context of any motives that influence the profession selection of online transportation drivers. This paper discusses driver motivation in working as an online transportation driver. This research is qualitative research. Data collection was obtained from observation, documentation and interviews with online transportation drivers in Semarang City The author found evidence that the election became the driver of online transportation not only because of economic motives but also social motives Limitations of this study have not discussed the motives of crimes committed by online transportation drivers. The practical implication of this research is that the positive motives of prospective drivers affect good service to online transportation consumers. Understanding the motives of prospective drivers can be used by transportation companies to reduce the risk of crimes committed by drivers.
\end{abstract}

Keywords: Drivers, Online Transportation, Economic Motives, Social Motives

\section{Introduction}

Technological developments have affected the transportation world in Indonesia. The Android and IOS technology applications are used for the development of transportation into online transportation [1]. Online transportation innovations attract consumers to use their services [2]. Customers can order a variety of services such as service delivery to a destination, food delivery services, shipping services and other services [3]. Payment for use of services can be made in cash or electronic money [4]. Currently, customers prefer online platform [5], so the services provided provide convenience, satisfaction, approval and affordable prices of services provided by conventional transportation [6]. The potential for large online transportation dominates the transportation market in Indonesia. Getting the transition from conventional transportation [7]. Conventional transportation considers that there is no clear agreement on online transportation [8]. Unclear regulations lead to frequent conflicts between online transportation drivers and conventional transportation [9].

The presence of online transportation is expected to reduce the number of unemployed people in Indonesia [10]. The relationship between drivers and online transportation companies is in the form of partnerships [11]. The company prepares applications and standard operating procedures while drivers prepare motorized vehicles [12]. Drivers will get equipment from the company in the form of helmets and jackets bearing company logos at affordable prices [13]. Distribution of income from each order is $80 \%$ for drivers and $20 \%$ for companies [14]. 
Revenues obtained by online transportation drivers are higher than city minimum wages [15]. Being a driver of online transportation is considered more prestigious than being a conventional motorcycle or taxi driver service [16].

Drivers who join online transportation form a community through social media platforms such as whatsapp and twitter. Community drivers are closely intertwined due to the similarity of identities [17]. They will greet each other if they meet on the street. The conflict between drivers of online transportation and conventional transportation has made the community of online transportation drivers increasingly solid [18]. The community of online transportation drivers is expected to be a solution to help drivers who are in trouble. Although there are many risks as online transportation drivers, the number of registrants to become online transportation drivers is very large. Currently registering as an online transportation driver has been limited. Restricting registration to drivers opens the practice of illegally buying driver accounts [19]. This phenomenon attracts researchers to analyze the motives that affect someone choosing an online transportation driver.

\section{Method}

This study used qualitative research methods. The location of this research is in Semarang City, Central Java. Data collection is obtained from observation, interviews and documentation. Data sources in this study used primary data sources obtained directly through interviews and observations with informants. The subjects in this study were drivers of online transportation around the city of Semarang which consisted of Go-Jek drivers and Grab drivers.

\section{Result and Discussion}

The researcher developed interview techniques and in-depth observation of the informants. In-depth interviews and observations are needed to get comprehensive research results regarding the motives of choosing the profession of online transportation drivers. Informants in this study used primary data sources, namely those who work as online transportation drivers. Informant search uses snowball sampling. The results of interview and profile observation of drivers surprised the researcher, because there were drivers who were from S1 students and S2 students

Table 1. Informant data based on driver profiles

\begin{tabular}{lll}
\hline Name & Age & Driver Profile \\
\hline Rizal & 25 Years & S2 Student \\
Fahreza & 21 Years & S1 Student \\
Supriyanto & 24 Years & Entrepreneurship \\
Ariawan & 29 Years & Factory Employees \\
Imran & 25 Years & Factory Employees \\
Sari Nurdianti & 35 Years & Housewife \\
Lusi & 23 Years & SPG \\
Romadhon & 27 Years & Full Driver \\
Agus Supriyanto & 30 Years & Full Driver \\
Sugiyanto & 52 Years & Full Driver \\
\hline
\end{tabular}


From Table 1 regarding informant data based on driver profiles. There are drivers who are running undergraduate and postgraduate studies at Semarang City State University. A driver with an entrepreneurial background. Two drivers also work as employees in one factory in the city of Semarang. There were two female informants, one as a housewife and one as a sales promotion girl. While three informants stated that the profession of online transportation drivers was his main job.

Max Weber's theory states that each individual has a motive in doing his work [20], as well as individuals who choose to work as online transportation drivers. The results of the research that the researchers got from the informants were quite surprising. The informant stated that the motive for being a driver was not only because of economic motives. The reason they become drivers is also because of social motives. Some informants even stated their reasons for being drivers of online transportation not because of economic motives, but because of social motives and other motives. During this time most people thought they were drivers of online transportation because of economic motives. Next, the researcher presents table 2 based on motive informant data as an online transportation driver.

Table 2. Motivational informant data becomes the online transportation driver.

\begin{tabular}{lll}
\hline Nama & Economic Motives & Social Motives \\
\hline Rizal & No & Yes \\
Fahreza & No & Yes \\
Supriyanto & No & Yes \\
Ariawan & Yes & Yes \\
Imran & Yes & Yes \\
Sari Nurdianti & Yes & Yes \\
Lusi & Yes & Yes \\
Romadhon & Yes & Yes \\
Agus Supriyanto & Yes & Yes \\
Sugiyanto & Yes & Yes \\
\hline
\end{tabular}

Based on Table 2 obtained information there are several drivers that do not have economic motives. Rizal became a driver because he join the community of drivers who have the same motorcycle as him. Rizal wants to share his knowledge about motorcycle maintenance with other drivers. Fahreza is an online transportation driver because he wants to avoid lecture routines. Fahreza feels comfortable gathering with the community of online transportation drivers. Supriyanto became a driver because he wanted to build social relations with fellow drivers and also with online transportation consumers. Supriyanto's conversation with his customers inspired many of the businesses he was running. While other drivers stated that despite their motives for being drivers of online transportation because of economic motives, they also had social motives. They chose to be drivers because of the ease in managing working hours, transparent revenue sharing, the opportunity to get a lot of customers and motives for reasons of wanting to join the community of drivers who have strong solidarity. 


\section{Conclusion}

The motive for choosing a profession to be an online transportation driver is not only because of economic motives. From the results of the study obtained data that the driver of online transportation chose to be a driver because of the motives of social relation 


\section{References}

[1] Marhayanie, Mrs, Mutia Ismail, and Iskandar Muda. "Impact of Smartphone Features on" Omset" Services Online Car Rental." In 1st Economics and Business International Conference 2017 (EBIC 2017). Atlantis Press, 2018.

[2] Yunus, Mahmud. "GO-JEK SEBAGAI SIMBOL PERUBAHAN SOSIAL DAN EKONOMI DI KOTA TEGAL." EQUILIBRIA PENDIDIKAN: Jurnal Ilmiah Pendidikan Ekonomi 2, no. 2 (2018): 59-68.

[3] Silalahi, Shilvia L. Br, Putu W. Handayani, and Qorib Munajat. "Service quality analysis for online transportation services: Case study of GO-JEK." Procedia Computer Science 124 (2017): 487-495

[4] Ferdiana, Agus Made Krisnan, and G. S. Darma. "Understanding Fintech Through GoPay." International Journal of Innovative Science and Research Technology 4, no. 2 (2019): 257-260.

[5] Farrell, Diana, Fiona Greig, and Amar Hamoudi. "The online platform economy in 2018: Drivers, workers, sellers, and lessors." JPMorgan Chase Institute (2018).

[6] Alamsyah, Andry, and Imam Rachmadiansyah. "Mapping online transportation service quality and multiclass classification problem solving priorities." In Journal of Physics: Conference Series, vol. 971, no. 1, p. 012021. IOP Publishing, 2018..

[7] Azzuhri, Abdul Adhim, Aisyah Syarafina, Frendy Tanoto Yoga, and Reski Amalia. "A Creative, Innovative, and Solutive Transportation for Indonesia with Its Setbacks and How to Tackle Them: A Case Study of the Phenomenal GOJEK." Review of Integrative Business and Economics Research 7 (2018): 59-67.

[8] Wahyuningtyas, Sih Yuliana. "The online transportation network in Indonesia: A pendulum between the sharing economy and ex ante regulation." Competition and Regulation in Network Industries 17, no. 3-4 (2016): 260-280.

[9] Esfandari, Diah Agung. "Gojek In Conflict: Cultural Perspective." In International Conference on Transformation in Communication (ICOTIC). 2015.

[10] Rifaldi, Rifaldi, Kadunci Kadunci, and Sulistyowati Sulistyowati. "Pengaruh Kualitas Pelayanan Transportasi Online Gojek Terhadap Kepuasan Pelanggan Pada Mahasiswa/i Administrasi Niaga Politeknik Negeri Jakarta." Epigram 13, no. 2 (2016).

[11] Indyaswari, Pande Putu Tara Anggita, and Dewa Nyoman Rai Asmara Putra. "Analisis Mengenai Hubungan Supir Go-Jek Dengan Pt. Gojek Indonesia." Kertha Semaya 5, no. 2 (2017): 1-7.

[12] Sutrisno, Tri. "Strategi Komunikasi Driver Gojek Dalam Menarik Simpati Pelanggan (Studi pada Komunitas Gojek Demang di Palembang)." PhD diss., UIN RADEN FATAH PALEMBANG, 2018.

[13] Pranoto, Agung Hadi. "Siasat Manipulatif Dalam Kompetisi Pengemudi Gojek di Kota Sura-baya." Jurnal Thesis Departemen Antro-pologi (2017): 1-10.

[14] Manueke, Manuela, Gustaaf Budi Tampi, and Very Londa. "Persepsi Masyarakat Tentang Jasa Transportasi Berbasis Aplikasi Online Di Kota Manado (Studi Kasus Di Pt. Go-Jek)." Jurnal Administrasi Publik 4, no. 51 (2018).

[15] GENEO, YONEKHA. "TINGKAT KESEJAHTERAAN DRIVER GOJEK DI KOTA PADANG ANALISIS INDIKATOR OBJEKTIF DAN SUBJEKTIF." PhD diss., Universitas Andalas, 2018.

[16] Anindhita, Wiratri, Melisa Arisanty, and Devie Rahmawati. "Analisis Penerapan Teknologi Komunikasi Tepat Guna Pada Bisnis Transportasi Ojek Online (Studi pada 
Bisnis Gojek dan Grab Bike dalam Penggunaan Teknologi Komuniasi Tepat Guna untuk Mengembangkan Bisnis Transportasi)." In Prosiding Seminar Nasional INDOCOMPAC. 2016.

[17] Natadjaja, Listia, and Paulus Benny Setyawan. "Creating Community through Design: The Case of GO-JEK Online." International Journal of Cultural and Creative Industries 4, no. 1 (2016): 18-27.

[18] Junior, Mega Swastika. "Fungsionalitas Konflik Gojek: Studi Fenomenologi Terhadap Konflik Pengemudi Gojek di Kota Kediri." Jurnal Analisa Sosiologi 6, no. 1 (2017).

[19] Susanti, Dyah Ochtorina, and Siti Nur Shoimah. "Implikasi Hukum Jual Beli Akun Pengemudi pada Layanan Jasa Taxi Online." Jurnal Supremasi 9, no. 1 (2019): 1-18.

[20] Weber, Max. Economy and society: An outline of interpretive sociology. Vol. 1. Univ of California Press, 1978. 